\title{
Career commitment and entrenchment among Primary Care nurses*
}

\author{
Comprometimento e entrincheiramento com a carreira entre enfermeiros da Atenção Primária* \\ Compromiso y atrincheramiento con la carrera entre enfermeros de la Atención Primaria*
}

How to cite this article:

Lourenção LG, Silva RAS, Moretti MSR, Sasaki NSGMS, Sodré PC, Gazetta CE. Career commitment and entrenchment among Primary Care nurses. Rev Esc Enferm USP. 2021;55:e20210186. https://doi.org/10.1590/1980-220X-REEUSP-2021-0186.

\section{iD Luciano Garcia Lourenção ${ }^{1}$ \\ (iD) Rosana Aparecida de Souza da Silva ${ }^{2}$ \\ (iD) Marli dos Santos Rosa Moretti \\ (iD) Natália Sperli Geraldes Marin dos Santos Sasaki² \\ Paula Canova Sodré ${ }^{3}$ \\ Claudia Eli Gazetta²}

\footnotetext{
* Extracted from the thesis: "Comprometimento e entrincheiramento com a carreira de enfermeiros da Atenção Primária à Saúde”, Faculdade de Medicina de São José do Rio Preto, Programa de Pós-Graduação em Enfermagem, 2021.

${ }^{1}$ Universidade Federal do Rio Grande, Rio Grande, RS, Brazil.

${ }^{2}$ Faculdade de Medicina de São José do Rio Preto, São José do Rio Preto, SP, Brazil.

${ }^{3}$ Secretaria Municipal de Saúde, São José do Rio Preto, SP, Brazil.
}

\begin{abstract}
Objective: To assess career commitment and entrenchment among Primary Care nurses. Method: This is a cross-sectional study, carried out in 2018, with primary care nurses from two cities in the state of São Paulo. The Career Commitment and Entrenchment Scales, validated in Brazil, and consisting of 12 items each, were used, and assess: identity, resilience, and planning, related to commitment; emotional costs, investments, and limitation of career alternatives, related to entrenchment. Results: The mean score of career commitment (61.4 points) was higher than that of career entrenchment (57.8 points); the identity factor had a high level (70.9 points); resilience and career planning obtained medium levels (62.5 and 50.8 points, respectively). Career entrenchment ( 57.8 points) and its respective factors reached medium levels (investments: 57.7 points; limitation of alternatives: 58.8 points; emotional costs: 57.0 points). Conclusion: The nurses showed a predominance of the career commitment relationship, as they showed a greater link of identification and positive relationship than of career stagnation.
\end{abstract}

\section{DESCRIPTORS}

Career Mobility; Occupational Health Nursing; Working Environment; Primary Health Care; Nursing. 


\section{INTRODUCTION}

The Primary Health Care (PHC) services represent the first level of care in the Brazilian public health system (SUS) and are considered the gateway for users to the public system; therefore, $\mathrm{PHC}$ workforce is required to increase the capacity to meet users' demands ${ }^{(1-2)}$. However, the increase in the number of professionals, the expansion of seasonal and informal work, doubts about the future, and the technological advances that have marked contemporary labor market affect people's relationships with work. Therefore, measuring the workers' relationships with their careers, such as commitment and entrenchment, which are characterized by discordant behaviors, capable of causing important organizational, social, and personal impacts ${ }^{(3-5)}$, becomes relevant.

Career commitment is related to the professional's engagement, dedication, and proactive posture with the organization and involves the workers' desirable behaviors in relation to their career and the organization ${ }^{(6-7)}$. Entrenchment, on the other hand, consists of the workers' tendency to remain in the career due to fear of losses and limitation in the perception of other professional opportunities ${ }^{(5)}$.

While the committed worker is involved with the organization, work and career, aiming at improving and overcoming the difficulties that arise, the entrenched worker is stagnant, in a defensive and static position, caused by feelings of emotional and economic loss, which keep him/her connected to his/her career and the work he/she performs ${ }^{(5-9)}$. Being entrenched can trigger feelings of fear, related to the risk of losing rights and benefits and the limitation of age to seek good job reinsertion, as well as the desire to avoid situations of emotional exhaustion and social stigma ${ }^{(5-6,10-12)}$.

The relationships of commitment and entrenchment with the career are manifested based on professionals' motivation ${ }^{(6,11-12)}$. Thus, it is important to find the reasons of the permanence of PHC nurses in the profession, since these professionals have a primordial role in the organization of work processes and in the management of health units, being responsible for participating in the planning, management, and assessment of the nursing team's and health agents' actions, as well as developing permanent education of the team's professionals, especially nursing assistants/technicians and health agents, predicting and providing inputs for the proper functioning of the unit ${ }^{(2)}$.

Nevertheless, knowing the levels of commitment and entrenchment relationships with the career presented by PHC nurses can favor actions directed to strengthen these professionals' personal and work development, and the consolidation of SUS health services. After all, these professionals are often under conditions of labor vulnerability, characterized by outsourced contracts, for a fixed period, with unstable employment relationships, low remuneration, and lack of staffing and compensation plans, which lead to high turnover, as well as dissatisfaction and lack of interest in workers, negatively impacting SUS's resolutive capacity ${ }^{(13-16)}$.

Some studies on the types of career relationships carried out with nurses show the predominance of the commitment relationship, compared to the entrenchment relationship ${ }^{(5)}$, and highlight that education, age, work sector, and length of professional performance interfere in the levels of commitment to the career ${ }^{(17-18)}$. However, the literature on this topic is still scarce, especially with regard to the relationships with the career of nurses working in PHC.

In view of all this, this study aimed at assessing career commitment and entrenchment among Primary Care nurses.

\section{METHOD}

\section{Type OF Study}

This is a cross-sectional, descriptive, and analytical study, carried out in 2018, with nurses from the Family Health teams in two Brazilian municipalities.

\section{LOCAL.}

The study was carried out in two Brazilian inland cities of the state of São Paulo, which were intentionally selected because of their links with researchers. The first municipality (Municipality A) is located $452 \mathrm{~km}$ from the capital, in the northern region of the state. It is a large municipality and, according to data from the Brazilian Institute of Geography and Statistics, has an estimated population of 438,354 inhabitants. The city is headquarters to the largest Regional Health Division in the state of São Paulo (DRS XV) and a reference in health care.

At the time of data collection, the municipality was geographically divided into five Health Districts and had 27 municipal Primary Health Care services, with 40 Family Health teams, responsible for covering $24 \%$ of the municipality's population.

The second municipality (Municipality B) is located in the western region of the state, $596 \mathrm{~km}$ from the capital. It has a population of 33,707 inhabitants, being considered a small municipality. The municipality is a reference center in the health area for nine municipalities in the region of the Nova Alta Paulista. According to the structure of the local health model, Primary Health Care was carried out by four Family Health units, with ten teams and coverage of $100 \%$ of the municipality's population.

\section{Population and Sample Definition}

The study population consisted of nurses from all Primary Health Care units in the municipalities, with an estimated 110 professionals in municipality A and 24 in municipality B, totaling 134 professionals. Nurses who were on a leave or on vacation during the data collection period were excluded from the study.

The sample consisted of 92 nurses (68.7\% of the total), 77 from municipality A (70\% of the population) and 15 from municipality B (62.5\% of the population).

\section{Data Collection}

Data were collected using three self-administered instruments, namely: an instrument developed by the researchers, with professional and sociodemographic variables; and the Career Commitment $(\mathrm{CCS})^{(9,19)}$ and Career Entrenchment $(\mathrm{CES})^{(10.20)}$ Scales, validated in Brazil.

The CCS consists of 12 items divided into three factors: identity (items 1, 2, 3, 4), resilience (items 5, 6, 7, 8), and 
planning (items 9, 10,11,12). The items comprise sentences regarding behaviors and attitudes related to the professional career ${ }^{(9)}$. The CES also contains 12 items, which assess the factors: investments (items 1, 2, 3, 4), emotional costs (items 5, 6, 7,8 ), and limitation of career alternatives (items 9, 10,11, 12). The CES items present feelings and perceptions related to the possibility of the professional changing careers ${ }^{(20)}$.

The researchers used team meetings to collect data, after scheduling with the health units managers. Initially, the study objectives were explained and, then, the questionnaires and the Free and Informed Consent Forms (FICF) were delivered in separate and sealed envelopes. Professionals were able to answer the questionnaires at work or at their homes, within a set period of up to seven days. After answering them, the questionnaires were returned in separate and sealed envelopes, to avoid the study participants identification.

For professionals who were not present at the meetings, the researchers left the questionnaires and the FICF with the unit managers, who delivered and collected them in separate and sealed envelopes, and handed them over to the researchers, later, within the maximum term of 30 days.

\section{Data Analysis and Treatment}

For data analysis, the software SPSS (Statistical Package for Social Sciences), version 20.0, was used. First, the data precision analysis was carried out through descriptive and exploratory statistical techniques, sample size analysis and description, and distribution of omitted cases. Data reliability was checked by Cronbach's Alpha indicator, which indicated $\alpha=0.792$ for career commitment and $\alpha=0.795$ for career entrenchment, values considered good reliability indicators ${ }^{(21)}$.

The characterization of the study population was performed using professional and sociodemographic variables. To check the levels of relationships established by nurses, the constructs mean score and standard deviation were initially calculated, on a scale from zero to 20 for each factor of the constructs: identity [(Mean.(CCS1,CCS2,CCS3,CCS4) * 5)], planning [(Mean. $(\mathrm{CCS} 5, \mathrm{CCS} 6, \mathrm{CCS} 7, \mathrm{CCS} 8 * 5)]$ and resilience [(Mean.(CCS9,CCS10,CCS11,CCS12)* 5)]; investments [(Mean. (CES1, CES2, CES3, CES4) * 5)], limitation of alternatives [(Mean. ( CES5, CES6, CES7, CES8) * 5)], and emotional costs [(Mean. (CES9, CES10), CES11, CES12) *5)]; and zero to 60 for the constructs commitment [(Mean.(CCS1, $\mathrm{CCS} 2, \mathrm{CCS} 3, \mathrm{CCS} 4, \mathrm{CCS} 5, \mathrm{CCS} 6, \mathrm{CCS} 7, \mathrm{CCS} 8, \mathrm{CCS} 9, \mathrm{CCS} 10$, CCS11,CCS12) * 5)] and career entrenchment [(Mean. (CES1, CES2,CES3,CES4,CES5,CES6,CES7,CES8,CES9,CES10, CES11,CES12) * 5)]. Then, each factor/construct means was standardized to a scale from zero to 100 points, using the formula: (factor/construct mean $* 100 / 20$ ), and categorized according to the mean value obtained as: low (zero to 33.3 points), medium (33.3 to 66.7 points), and high ( 66.7 to 100.0 points).

Finally, the difference between the levels of relationships with the career was checked, according to sociodemographic and professional variables, using the $t$ test or analysis of variance (ANOVA) to compare the means and considering significant values of $\mathrm{p} \leq 0.05$.

\section{Ethical Aspects}

In compliance with the requirements of the National Health Council for studies involving human beings, the project was submitted for analysis by the Research Ethics Committee of the São José do Rio Preto Medical School and approved with Opinion no. 2.412.726, of December 4, 2017. The Free Informed Consent Form was signed by all professionals who participated in the study.

\section{RESULTS}

A total of 92 nurses participated in the study, 77 (83.7\%) from municipality A and 15 (16.3\%) from municipality B. There was a prevalence of female professionals (93.5\%\%); aged between 31 and 40 years (44.6\%), median of 37 years; married $(60.9 \%)$; with a graduate certificate $(81.5 \%)$; selected for public positions (70.7\%); family income from six to 10 minimum wages (44.6\%); health unit managers (43.5\%); and working in PHC between two and five years (28.3\%), as shown in Table 1.

The results of career relationships showed that nurses had a higher mean for the construct career commitment (61.4 points) than for career entrenchment (57.8 points). Regarding career commitment, the factor identity with the career had the highest mean, classified as high (70.9 points). The factors career resilience and career planning had scores classified as mean values (62.5 and 50.8 points, respectively) (Table 2 ).

Regarding career entrenchment, there was an average level for the construct (57.8 points) and its three factors [career investments $=57.7$ points; limitations of career alternatives $=$ 58.8 points; career emotional costs $=57.0$ points $]$. The standard deviations presented were low, showing low variability in the nurses' responses (Table 2).

Table 3 shows the levels of nurses' career relationships, according to the municipality studied, and points out that there was no significant difference in the levels of career relationships obtained by nurses in the two cities. Professionals from both municipalities had a high level of relationship in the factor identification with career [municipality $\mathrm{A}=70.7$ points; municipality $\mathrm{B}=72.0$ points]. For the other factors and constructs (commitment and entrenchment), the levels of relationship with the career were mean values.

It was observed, however, that nurses from municipality B presented levels of commitment to their career (62.4 points) slightly higher than those from municipality A (61.2 points). The same occurred for the factors identification with the career [municipality $\mathrm{B}=72.0$ points; municipality $\mathrm{A}=70.7$ points] and career planning [municipality $\mathrm{B}=55.0$ points; municipality $A=50.0$ points]. For the factor career resilience, nurses from municipality A had higher levels than those from municipality B (62.9 versus 60.3 points, respectively).

Regarding career entrenchment, the mean obtained by nurses from municipality B (59.0 points) was higher than that obtained by professionals from municipality A ( 57.6 points). The opposite occurred with the factor career investments, that is, it was slightly higher in municipality A (58.3 points) compared to municipality B (55.0 points). 
Table 1 - Professional and sociodemographic characteristics of PHC nurses in the cities studied. São Paulo, Brazil, 2018.

\begin{tabular}{|c|c|c|}
\hline \multirow{2}{*}{ Variables } & Municipality A & Municipality B \\
\hline & n (\%) & n (\%) \\
\hline Total & 77 (100.0) & $15(100.0)$ \\
\hline \multicolumn{3}{|l|}{ Sex } \\
\hline Male & $5(5.2)$ & $1(6.7)$ \\
\hline Female & $72(93.5)$ & $14(93.3)$ \\
\hline Did not answer & $1(1.3)$ & - \\
\hline \multicolumn{3}{|l|}{ Age range } \\
\hline From 20 to 30 years & $16(20.8)$ & $1(6.7)$ \\
\hline From 31 to 40 years & $32(41.6)$ & $9(60.0)$ \\
\hline From 41 to 50 years & $19(24.7)$ & $3(20.0)$ \\
\hline 51 years or above & $6(7.8)$ & $2(13.3)$ \\
\hline Did not answer & $4(5.2)$ & - \\
\hline
\end{tabular}

\begin{tabular}{ccc}
\hline Marital status & & \\
Married & $44(57.1)$ & $12(80.0)$ \\
Single & $27(35.1)$ & $2(13.3)$ \\
Divorced & $5(6.5)$ & - \\
Widow(er) & $1(1.3)$ & $1(6.7)$ \\
\hline Level of education & & $3(20.0)$ \\
Undergraduate course & $10(13.0)$ & $12(80.0)$ \\
Graduate certificate & $63(81.8)$ & - \\
Master degree & $2(2.6)$ & - \\
PhD & $2(2.6)$ &
\end{tabular}

\begin{tabular}{ccc}
\hline Type of agreement & & \\
Selected for public job & $53(68.8)$ & $12(80.0)$ \\
Hired & $24(31.2)$ & $3(20.0)$ \\
\hline
\end{tabular}

Family income (in minimum salaries)*

$\begin{array}{ccc}\text { Two to five } & 24(31.2) & 10(66.7) \\ \text { Six to } 10 & 39(50.6) & 2(13.3) \\ \text { More than } 10 & 12(15.6) & 3(20.0) \\ \text { Did not answer } & 2(2.6) & -\end{array}$

Health unit manager

\begin{tabular}{lll} 
Yes & $31(40.3)$ & $9(60.0)$ \\
No & $46(59.7)$ & $6(40.0)$ \\
\hline
\end{tabular}

Length of work at PHC

\begin{tabular}{ccc} 
Up to two years & $17(22.1)$ & $2(13.3)$ \\
Two to five years & $21(27.3)$ & $5(33.3)$ \\
Six to 10 years & $16(20.8)$ & $2(13.3)$ \\
11 to 20 years & $20(26.0)$ & $4(26.7)$ \\
More than 20 years & $1(1.3)$ & $2(13.3)$ \\
\hline
\end{tabular}

*Minimum salary: $\mathrm{R} \$ 937.00$.

In the factors limiting career alternatives and emotional costs in the career, municipality $\mathrm{B}$ had higher averages than municipality A, as shown in Table 3.

Regarding the levels of nurses' career commitment and entrenchment, according to sociodemographic and professional characteristics (Table 4), it was observed that the level of identification with the career was significantly higher among
Table 2 - Standardized means and standard deviations ( \pm sd) for the constructs and factors of the types of career relationships and their respective classification. São Paulo, Brazil, 2018.

\begin{tabular}{ccc}
\hline Relationships with career & Standardized means $( \pm$ sd) & Classification \\
\hline Career commitment & $\mathbf{6 1 . 4}( \pm 6.8)$ & Medium \\
Identification with career & $70.9( \pm 10.3)$ & High \\
Planning with career & $50.8( \pm 10.5)$ & Medium \\
Resilience with career & $62.5( \pm 17.5)$ & Medium \\
\hline $\begin{array}{c}\text { Entrenchment with } \\
\text { career }\end{array}$ & $\mathbf{5 7 . 8}( \pm 7.6)$ & Medium \\
$\begin{array}{c}\text { Investments in the career } \\
\text { Limitation of alternatives } \\
\text { in the career }\end{array}$ & $57.7( \pm 18.2)$ & Medium \\
$\begin{array}{c}\text { Emotional costs in the } \\
\text { career }\end{array}$ & $58.8( \pm 8.7)$ & Medium \\
\hline
\end{tabular}

Table 3 - Standardized means and standard deviations ( \pm sd) for the constructs and factors of the types of career relationships and their respective classification. São Paulo, Brazil, 2018.

\begin{tabular}{cccc}
\hline \multirow{2}{*}{ Relationships with career } & \multicolumn{2}{c}{ Standardized means $( \pm$ sd) } & \\
\cline { 2 - 3 } & Municipality A & Municipality B & \\
\hline Career commitment & $\mathbf{6 1 . 2}( \pm 7.2)^{\mathrm{a}}$ & $\mathbf{6 2 . 4}( \pm 4.3)^{\mathrm{a}}$ & 0.833 \\
Identification with careers & $70.7( \pm 9.5)^{\mathrm{b}}$ & $72.0( \pm 14.0)^{\mathrm{b}}$ & 0.779 \\
Planning with career & $50.0( \pm 10.4)^{\mathrm{a}}$ & $55.0( \pm 10.0)^{\mathrm{a}}$ & 0.286 \\
Resilience with career & $62.9( \pm 17.9)^{\mathrm{a}}$ & $60.3( \pm 15.9)^{\mathrm{a}}$ & 0.460 \\
\hline $\begin{array}{c}\text { Career entrenchment } \\
\text { Investments in the career }\end{array}$ & $\mathbf{5 7 . 6 ( \pm 7 . 3 ) ^ { \mathrm { a } }}$ & $\mathbf{5 9 . 0}( \pm 8.7)^{\mathrm{a}}$ & 0.346 \\
Limitation of alternatives in & $58.1( \pm 9.0)^{\mathrm{a}}$ & $62.4( \pm 6.3)^{\mathrm{a}}$ & 0.115 \\
the career & $55.0( \pm 20.2)^{\mathrm{a}}$ & 0.963 \\
$\begin{array}{c}\text { Emotional costs in the } \\
\text { career }\end{array}$ & $56.4( \pm 10.1)^{\mathrm{a}}$ & $59.7( \pm 10.3)^{\mathrm{a}}$ & 0.495 \\
\hline
\end{tabular}

${ }^{*}$ Test t. ${ }^{\mathrm{a}}$ Medium Level. ${ }^{\mathrm{b}}$ High Level.

hired nurses $(p=0.033)$, showing that these professionals have a greater emotional connection with their career.

Regarding the factors of the construct career entrenchment, the level of emotional costs in the career was higher among male nurses $(p=0.016)$; the level of career investments among those with a master degree and a graduate certificate was higher than that of $\mathrm{PhDs}$ and undergraduates $(p=0.044)$.

Professionals selected for work in public agencies showed greater loss of investments in case of career change $(p=0.015)$, while professionals hired by private places had higher emotional costs in case of career change $(p=0.012)$.

The length of experience in PHC also influenced the factors of career entrenchment. Higher scores for limitation of career alternatives were observed among nurses who had two to five years or more than 20 years of professional experience in PHC $(p=0.022)$. Nurses with up to two years of experience in PHC, in their turn, had higher emotional costs in case of career change $(p=0.040)$.

There were no significant differences in the levels of career relationships in relation to age group, marital status, family income and being a health unit manager or not $(p>0.05)$. 
Table 4 - Standardized means and standard deviations $( \pm \mathrm{sd})$ for the constructs and factors of the types of relationships with the career, according to the sociodemographic and professional characteristics of nurses in Primary Care. São Paulo, Brazil, 2018.

\begin{tabular}{|c|c|c|c|c|c|c|c|c|}
\hline \multirow{2}{*}{$\begin{array}{l}\text { Sociodemographic and } \\
\text { professional variables }\end{array}$} & \multicolumn{4}{|c|}{ Career commitment } & \multicolumn{4}{|c|}{ Career entrenchment } \\
\hline & Identification & Planning & Resilience & $\begin{array}{c}\text { General } \\
\text { construct }\end{array}$ & Investments & $\begin{array}{l}\text { Limitation of } \\
\text { alternatives }\end{array}$ & $\begin{array}{l}\text { Emotional } \\
\text { costs }\end{array}$ & $\begin{array}{c}\text { General } \\
\text { construct }\end{array}$ \\
\hline \multicolumn{9}{|l|}{ Sex } \\
\hline Male & $67.0( \pm 6.7)^{\mathrm{a}}$ & $51.0( \pm 10.2)^{\mathrm{a}}$ & $58.0( \pm 13.0)^{\mathrm{a}}$ & $58.7( \pm 8.8)^{\mathrm{a}}$ & $52.2( \pm 14.4)^{\mathrm{a}}$ & $63.0( \pm 2.7)^{\mathrm{a}}$ & $60.0( \pm 5.0)^{\mathrm{a}}$ & $58.3( \pm 5.9)^{\mathrm{a}}$ \\
\hline Female & $71.3( \pm 10.3)^{\mathrm{b}}$ & $50.7( \pm 10.5)^{\mathrm{a}}$ & $62.6( \pm 17.8)^{\mathrm{a}}$ & $61.5( \pm 6.7)^{\mathrm{a}}$ & $58.3( \pm 18.4)^{\mathrm{a}}$ & $58.5( \pm 8.9)^{\mathrm{a}}$ & $57.0( \pm 10.2)^{\mathrm{a}}$ & $57.9( \pm 7.6)^{\mathrm{a}}$ \\
\hline$p$-value & 0.363 & 0.237 & 0.950 & 0.487 & 0.882 & 0.398 & 0.016 & 0.270 \\
\hline Undergraduate course & $72.7( \pm 10.1)^{\mathrm{b}}$ & $50.4( \pm 6.3)^{\mathrm{a}}$ & $58.9( \pm 15.6)^{\mathrm{a}}$ & $60.6( \pm 5.1)^{\mathrm{a}}$ & $49.6( \pm 21.6)^{\mathrm{a}}$ & $57.8( \pm 8.5)^{\mathrm{a}}$ & $54.6( \pm 11.6)^{\mathrm{a}}$ & $54.0( \pm 9.0)^{\mathrm{a}}$ \\
\hline Graduate certificate & $70.9( \pm 10.2)^{\mathrm{b}}$ & $51.5( \pm 10.6)^{\mathrm{a}}$ & $63.2( \pm 17.9)^{\mathrm{a}}$ & $61.8( \pm 6.8)^{\mathrm{a}}$ & $59.4( \pm 17.1)^{\mathrm{a}}$ & $58.9( \pm 9.0)^{\mathrm{a}}$ & $57.7( \pm 9.9)^{\mathrm{a}}$ & $58.6( \pm 7.0)^{\mathrm{a}}$ \\
\hline Master's degree & $67.5( \pm 17.7)^{\mathrm{a}}$ & $45.0( \pm 7.1)^{\mathrm{a}}$ & $62.5( \pm 17.7)^{\mathrm{a}}$ & $58.3( \pm 14.1)^{\mathrm{a}}$ & $65.0( \pm 14.1)^{\mathrm{a}}$ & $65.0( \pm 0.0)^{\mathrm{a}}$ & $55.0( \pm 7.1)^{\mathrm{a}}$ & $61.7( \pm 7.1)^{\mathrm{a}}$ \\
\hline $\mathrm{PhD}$ & $62.5( \pm 10.6)^{\mathrm{a}}$ & $35.0( \pm 21.2)^{\mathrm{a}}$ & $60.0( \pm 28.3)^{\mathrm{a}}$ & $52.5( \pm 1.2)^{\mathrm{a}}$ & $40.0( \pm 28.3)^{\mathrm{a}}$ & $57.5( \pm 3.5)^{\mathrm{a}}$ & $47.5( \pm 10.6)^{\mathrm{a}}$ & $48.3( \pm 11.8)^{\mathrm{a}}$ \\
\hline Hired & $72.0( \pm 11.7)^{\mathrm{b}}$ & $47.6( \pm 10.8)^{\mathrm{a}}$ & $57.6( \pm 18.0)^{\mathrm{a}}$ & $59.1( \pm 6.8)^{\mathrm{a}}$ & $50.4( \pm 20.9)^{\mathrm{a}}$ & $59.1( \pm 10.0)^{\mathrm{a}}$ & $55.2( \pm 11.1)^{\mathrm{a}}$ & $54.9( \pm 9.3)^{\mathrm{a}}$ \\
\hline$p$-value & 0.033 & 0.485 & 0.056 & 0.084 & 0.015 & 0.012 & 0.860 & 0.282 \\
\hline \multicolumn{9}{|l|}{ Length of work at PHC } \\
\hline Up to two years & $75.0( \pm 10.3)^{\mathrm{b}}$ & $48.4( \pm 9.0)^{\mathrm{a}}$ & $53.4( \pm 17.6)^{\mathrm{a}}$ & $58.9( \pm 7.5)^{\mathrm{a}}$ & $47.9( \pm 20.5)^{\mathrm{a}}$ & $54.5( \pm 9.7)^{\mathrm{a}}$ & $61.6( \pm 9.1)^{\mathrm{a}}$ & $54.6( \pm 9.4)^{\mathrm{a}}$ \\
\hline Two to five years & $69.4( \pm 10.7)^{\mathrm{a}}$ & $53.3( \pm 11.9)^{\mathrm{a}}$ & $62.9( \pm 16.7)^{\mathrm{a}}$ & $61.9( \pm 6.4)^{\mathrm{a}}$ & $55.4( \pm 15.9)^{\mathrm{a}}$ & $61.9( \pm 8.3)^{\mathrm{a}}$ & $56.4( \pm 9.2)^{\mathrm{a}}$ & $57.9( \pm 5.5)^{\mathrm{a}}$ \\
\hline Six to 10 years & $67.8( \pm 9.4)^{\mathrm{a}}$ & $50.6( \pm 8.0)^{\mathrm{a}}$ & $70.0( \pm 16.9)^{\mathrm{b}}$ & $62.8( \pm 6.3)^{\mathrm{a}}$ & $63.9( \pm 11.8)^{\mathrm{a}}$ & $59.7( \pm 6.5)^{\mathrm{a}}$ & $56.7( \pm 9.2)^{\mathrm{a}}$ & $60.1( \pm 5.3)^{\mathrm{a}}$ \\
\hline 11 to 20 years & $72.1( \pm 9.8)^{\mathrm{b}}$ & $49.6( \pm 12.2)^{\mathrm{a}}$ & $62.7( \pm 17.8)^{\mathrm{a}}$ & $61.6( \pm 7.0)^{\mathrm{a}}$ & $62.3( \pm 20.7)^{\mathrm{a}}$ & $57.2( \pm 9.0)^{\mathrm{a}}$ & $55.4( \pm 12.5)^{\mathrm{a}}$ & $58.3( \pm 9.3)^{a}$ \\
\hline Above 20 years & $63.3( \pm 11.5)^{\mathrm{a}}$ & $55.0( \pm 8.7)^{\mathrm{a}}$ & $60.0( \pm 8.7)^{\mathrm{a}}$ & $59.4( \pm 2.5)^{\mathrm{a}}$ & $71.7( \pm 7.6)^{\mathrm{b}}$ & $63.3( \pm 5.8)^{\mathrm{a}}$ & $50.0( \pm 0.0)^{\mathrm{a}}$ & $61.7( \pm 4.4)^{\mathrm{a}}$ \\
\hline$p$-value & 0.468 & 0.129 & 0.536 & 0.074 & 0.221 & 0.022 & 0.040 & 0.205 \\
\hline
\end{tabular}

${ }^{a}$ Medium Level. ${ }^{\mathrm{b}}$ High level.

\section{DISCUSSION}

The profile described in the literature of higher education professionals working in PHC corroborates the profile of the nurses in this study, mostly made up of married women, aged less than 40 years and graduates, with experience in PHC between two and five years ${ }^{(13,15,22)}$.

The fact that nurses have a formal and stable employment relationship is positive for the health system, as it contributes to the strengthening of municipal management, especially in the implementation of long-term actions, ensuring the continuity of health care for the population. In addition, if the municipality has a career path that ensures professional growth and valorization, it can lead to an increase in professional satisfaction and an expansion of the health system's local resoluteness. Likewise, this stability favors increased levels of career commitment, especially in the factor career planning ${ }^{(23-24)}$.

The role of nurses as managers of $\mathrm{PHC}$ services is consistent with the literature, which indicates a large number of professionals exercising this function in large cities, where the position of manager is common. The creation and formalization of this position allows the definition of the necessary competencies for the professionals who will hold it, establishing salaries consistent with the position/function, to strengthen the service management process, generating positive impacts on the resolution of healthcare actions ${ }^{(25)}$.

The achievement of average levels of career commitment and entrenchment by nurses corroborates the national literature on the subject ${ }^{(5)}$. However, studies with $\mathrm{Saudi}^{\left({ }^{(17)}\right.}$ and Egyptian $^{(18)}$ nurses indicated high levels of career commitment among professionals. This result may be a reflection of the work process of Brazilian nurses in PHC, which, in addition to the growing demand from users, presents difficulties such as the insufficient number of nursing professionals in the teams, the overload with clinical-assistance, administrative, and management activities, the structural deficit of the health units, the precariousness of employment relationships and the lack of recognition of the nurses' work by the services managers and users ${ }^{(26)}$.

The literature points out that the social support received by nurses positively impacts the level of commitment of professionals to their career ${ }^{(17-18)}$. However, the fact that Nursing is not a highly valued profession in Brazil and that it was historically formed under the scope of charity and volunteering ${ }^{(27)}$ can contribute to the reduction of levels of commitment to the career found among Brazilian nurses in relation to professionals from other countries.

On the other hand, the high level of identification with the career shows that PHC nurses want to grow and be recognized 
professionally. In this context, it is understandable that the nurses hired at private institutions have presented a significantly higher level of identification with the career than those who have been selected for public positions, as by standing out in their careers, these professionals gain recognition and reduce the risk of having their contracts terminated.

Nevertheless, the high identification with the career is a positive aspect, as the focus on the career can increase the possibility for professionals to invest in their skills and knowledge, contributing to the increase of their professional performance and autonomy, as well as favoring strengthening of career development and increased professional satisfaction ${ }^{(28-29)}$.

Moreover, nurses showed good levels of resilience with their careers, that is, they have good ability to adapt and overcome adverse situations, very common in the Brazilian public health system, such as overcrowding, lack of professionals, equipment and materials, cuts of financial resources, among others ${ }^{(30)}$. Professionals with good levels of career resilience are seen as capable of working as a team, articulating independence and cooperation, important aspects to meet the prerogatives of the National Primary Care Policy, which was revised in 2017, and brought new guidelines for the organization of PHC teams within $\operatorname{SUS}^{(2)}$.

The average levels of career investments, limitation of career alternatives and emotional costs in the career presented by PHC nurses corroborate Brazilian studies with health professionals ${ }^{(5,29)}$. They also show that, among PHC nurses, the influence of the entrenchment relationship is lower than the influence of the career commitment relationship, that is, it is not the lack of alternatives for professional work, the emotional costs or the lost investments in case of career changes that oblige nurses to remain in the PHC services of the municipalities, but the desire to develop their career.

The differences in the levels of career relationships observed among professionals from different municipalities, although not statistically significant, may be related to the organizational and managerial reality of the municipalities, as well as to job opportunities and growth prospects.

In small towns, where job opportunities for nurses are reduced and the public system is an important employer, it is understandable that professionals have difficulty finding other professional alternatives outside the PHC and suffer emotional losses in case of a change of occupation, reason that leads them to show a strong emotional connection with their career in $\mathrm{PHC}$ and greater ability to set goals for the development of this career. On the other hand, in large cities, where the demands from services are more intense and exhausting, nurses are expected to have a high capacity to face adversity and, in case of career change, to lose more investments.

The greater emotional connection with the career, presented by hired nurses in relation to those selected in public examinations, was also found in a study with Saudi nurses ${ }^{(17)}$ and can be explained by the instability of work relationship of the hired professionals. On the other hand, because they have job stability, the nurses selected in public examinations had higher emotional costs in the event of a possible career change, as these professionals tend to plan better and invest more in their careers, since stability at the job provides greater possibilities for development and growth in the work environment, throughout the professional path. In this context, the literature highlights that there are great career differences between the public and private sectors, and the stability offered to selected professionals allows them to be continuously qualified, which is not always the case with hired professionals ${ }^{(11,17)}$.

\section{CONCLUSION}

The study showed that career commitment was the predominant relationship among $\mathrm{PHC}$ nurses, that is, professionals showed a deeper identification and positive relationship than stagnation with career.

Moreover, the results on the analysis of career commitment and entrenchment among PHC nurses, obtained in this study, contribute to the Primary Care management process and favor the direction of personal and labor development actions of these professionals, aimed at the structuring and strengthening of a career proposal that contributes to consolidate FHS as a model of health care at SUS, supporting the advancement of this system, with increased coverage and universal access to PHC services.

The main limitation of this study is its development before the onset of the Covid-19 pandemic, which led to the nurses' exposure to risks of infection by SARS-CoV-2, and prior to the declaration of the "International Year of the Nurse and Midwife" by the Pan American Health Organization (PAHO) and the World Health Organization (WHO), which aimed to value the work of professionals and highlight the challenges of the profession. Therefore, the results obtained were not negatively influenced by risks related to fighting the pandemic, nor positively influenced by possible investments and improvements in working conditions and professional development carried out as a result of the "Year of the Nurse".

However, new studies are required and important to find the reasons for the permanence of nurses in the profession, after the year 2020, marked by the campaign to value Nursing and by the fight against the Covid-19 pandemic.

\section{RESUMO}

Objetivo: Avaliar o comprometimento e o entrincheiramento com a carreira entre enfermeiros de serviços da Atenção Primária à Saúde. Método: Trata-se de um estudo transversal, realizado em 2018, com enfermeiros da atenção primária de dois municípios paulistas. Foram utilizadas as Escalas de Comprometimento e de Entrincheiramento com a Carreira, validadas no Brasil, e composta por 12 itens cada, que avaliam: identidade, resiliência e planejamento, relacionados ao comprometimento; custos emocionais, investimentos e limitação de alternativas na carreira, referentes ao entrincheiramento. Resultados: O escore médio do comprometimento (61,4 pontos) foi maior do que o de entrincheiramento com a carreira (57,8 pontos); o fator identidade obteve nível alto ( 70,9 pontos); resiliência e planejamento na carreira obtiveram níveis médios ( 62,5 e 50,8 pontos, respectivamente). O entrincheiramento com a carreira ( 57,8 pontos) e seus respectivos fatores atingiram níveis médios (investimentos: 57,7 pontos; limitação de alternativas: 58,8 pontos; custos emocionais: 57,0 pontos). Conclusão: Os enfermeiros apresentaram predomínio do vínculo de comprometimento com a carreira, pois apresentaram maior vínculo de identificação e relação positiva do que de estagnação com a carreira. 
DESCRITORES

Mobilidade Ocupacional; Enfermagem do Trabalho; Ambiente de Trabalho; Atenção Primária à Saúde; Enfermagem.

\section{RESUMEN}

Objetivo: Evaluar el compromiso y el atrincheramiento con la carrera entre enfermeros de cuidados de la Atención Primaria a la Salud. Método: Ha sido realizado un estudio transversal en 2018, con enfermeros de la atención primaria de dos ciudades paulistas. Se utilizaron las Escalas de Compromiso y de Atrincheramiento con la Carrera, convalidadas en Brasil, y compuesta por 12 temas cada, que evalúan: identidad, resiliencia y planificación, relacionados al compromiso; costos emocionales, inversiones y limitación de alternativas en la carrera, referentes al atrincheramiento. Resultados: El score promedio del compromiso (61,4 puntos) fue mayor del que el de atrincheramiento con la carrera (57,8 puntos); el factor identidad obtuvo nivel alto (70,9 puntos); resiliencia y planificación en la carrera obtuvieron niveles medios (62,5 y 50,8 puntos, respectivamente). El atrincheramiento con la carrera (57,8 puntos) y sus respectivos factores obtuvieron niveles medios (inversiones: 57,7 puntos; limitación de alternativas: 58,8 puntos; costos emocionales: 57,0 puntos). Conclusión: Los enfermeros presentaron en mayor proporción gran vínculo de compromiso con la carrera, una vez que presentaron mayor vínculo de identificación y relación positiva, más que de estagnación con la carrera.

\section{DESCRIPTORES}

Movilidad Laboral; Enfermería del Trabajo; Ambiente de Trabajo; Atención Primaria de Salud; Enfermería.

\section{REFERENCES}

1. Pinho ECC, Cunha TAN, Lemos M, Ferreira GRON, Lourenção LG, Pinheiro HHC, et al. Acesso e acessibilidade na atenção primária à saúde no Brasil. Enferm. Foco. 2020; 11(2):168-175. DOI: http://dx.doi.org/10.21675/2357-707X.2020.v11.n2.3449.

2. Brasil. Ministério da Saúde. Portaria n. 2.436, de 21 de setembro de 2017. Aprova a Política Nacional de Atenção Básica, estabelecendo a revisão de diretrizes para a organização da Atenção Básica, no âmbito do Sistema Único de Saúde (SUS) [Internet]. Brasília; 2017 [cited 2021 Jan 18 ]. Available from: http://pesquisa.in.gov.br/imprensa/jsp/visualiza/index.jsp?data=22/09/2017\&jornal=1 \&pagina=68\&totalArquivos=120.

3. Krein JD. O desmonte dos direitos, as novas configurações do trabalho e o esvaziamento da ação coletiva: consequências da reforma trabalhista. Tempo soc. 2018;30(1):77-104. DOI: http://dx.doi.org/10.11606/0103-2070.ts.2018.138082.

4. Mata ALS, Almeida SNC. Automação laboral e as novas relações trabalhistas: perquirições introdutórias da proteção jurídica do trabalhador. Argumenta Journal Law. 2020 [cited 2021 Jan 18];32:155-174. Available from: http://seer.uenp.edu.br/index.php/argumenta/article/ view/1768.

5. Lima MP, Costa VMF, Lopes LFD, Balsan LAG, Santos AS, Tomazzoni GC. Levels of career commitment and career entrenchment of nurses from public and private hospitals. Rev. Latino-Am. Enfermagem. 2015;23(6):1033-40. DOI: http://dx.doi.org/10.1590/0104-1169.0211.2646.

6. Tomazzoni GC, Costa VMF. Antecedents and consequences of organizational commitment, entrenchment, and consent. Cad. EBAPE.BR. 2020;18(2):268-283. DOI: http://dx.doi.org/10.1590/1679-395175056.

7. Balsan L, Costa V, Bastos A, Lopes L, Lima M, Santos A. The influence of commitment, entrenchment and support of transfer on the impact of training at work. Rev. Adm. UFSM. 2018;10(6):976-989. DOI: http://dx.doi.org/10.5902/1983465913316.

8. Katz IM, Rudolph CW, Zacher H. Age and career commitment: Meta-analytic tests of competing linear versus curvilinear relationships. J Vocat Behav. 2019;112:396-416. DOI: http://dx.doi.org/10.1016/j.jvb.2019.03.001.

9. Magalhães MO. Propriedades psicométricas da versão brasileira da escala de comprometimento com a carreira. Psicol. cienc. prof. 2013;33(2):303-17. DOl: http://dx.doi.org/10.1590/S1414-98932013000200005.

10. Carson KD, Carson PP, Bedeian AG. Development and construct validation of a career entrenchment measure. J Occup Organ Psychology. 1995;68(4):301-20. DOI: https://doi.org/10.1111/j.2044-8325.1995.tb00589.x.

11. Tomazzoni GC, Costa VMF, Antonello CS, Rodrigues MB. The Organisational Ties in the Perception of the Management: Commitment, Entrenchment and Consent. Rev. adm. contemp. 2020;24(3):245-258. DOI: https://doi.org/10.1590/1982-7849rac2020190119.

12. Araújo RA, Furtado VA, Lima TCB, Pinho APM. Stay because I need to? Permanency and entrenchment in teacher careers within public education. Educ. Policy Anal. Arch. 2020;28:(52):1-34. DOI: http://dx.doi.org/10.14507/epaa.28.4878.

13. Cordioli DFC, Cordioli Jr JR, Gazzeta CE, Silva AG, Lourenção LG. Occupational stress and work engagement in primary health care workers. Rev Bras Enferm. 2019;72(6):1580-1587. DOI: http://dx.doi.org/10.1590/0034-7167-2018-0681.

14. Alvarenga EC, Oliveira PTR, Pinheiro HHC, Carneiro VCCB. Condições de trabalho de equipes de saúde da família do Pará [Internet]. Rev. NUFEN. 2018 [cited 2021 Jan 18]; 10(1):58-72. Available from: http://pepsic.bvsalud.org/scielo.php?script=sci_arttext\&pid=S2175-25912018000100005\&ln $\mathrm{g}=\mathrm{pt} \& \mathrm{nrm}=$ iso.

15. Cordioli Junior JR, Cordioli DFC, Gazetta C, Silva AG, Lourenção LG. Quality of life and osteomuscular symptoms in workers of primary health care. Rev Bras Enferm. 2020;73(5):e20190054. DOI: http://dx.doi.org/10.1590/0034-7167-2019-0054.

16. Damascena DM, Vale PRLF. Tipologias da precarização do trabalho na atenção básica: um estudo netnográfico. Trab. educ. saúde. 2020;18(3):e00273104. DOI: http://dx.doi.org/10.1590/1981-7746-sol00273.

17. Azim MT, Islam MM. Social Support, Religious Endorsement, and Career Commitment: A Study on Saudi Nurses. Behav Sci (Basel). 2018;8(1):8. DOI: http://dx.doi.org/10.3390/bs8010008.

18. Elewa AH, Abed F. Nursing Profession as Perceived by Staff Nurses and Its Relation to Their Career Commitment at Different Hospitals. IJND. 2017 [cited 2021 Jan 18];7(1):13-22. Available from: https://nursingdidactics.com/index.php/ijnd/article/download/1892/1544.

19. Carson KD, Bedeian AG. Career commitment: construction of a measure and examination of its psychometric properties. J. Vocat. Behav. 1994;44(3):237-262. DOI: https://doi.org/10.1006/jvbe.1994.1017.

20. Magalhães MO. Propriedades psicométricas da versão brasileira da Escala de Entrincheiramento na Carreira. PsicoUSF [Internet]. 2008 [cited 2021 Feb 02];13(1):13-19. Available from: http://pepsic.bvsalud.org/scielo.php?script=sci_arttext\&pid=S1413-82712008000100003\&lng=pt\&nrm=iso. 
21. Souza AC, Alexandre NMC, Guirardello EB. Psychometric properties in instruments evaluation of reliability and validity. Epidemiol. Serv. Saúde. 2017;26(3):649-659. DOI: http://dx.doi.org/10.5123/s1679-49742017000300022.

22. Silva AG, Cabrera EMS, Gazetta CE, Sodré PC, Castro JR, Cordioli Jr JR, et al. Engagement in primary health care nurses: A cross-sectional study in a Brazilian city. Public Health Nurs. 2020;37(2):169-177. DOI: http://dx.doi.org/10.1111/phn.12694.

23. Souza GC, Aguiar CVN, Carneiro LL. A influência dos vínculos com a organização sobre o bem-estar subjetivo do trabalhador. Rev. Psicol., Organ. Trab. 2018;18(4):460-467. DOI: http://dx.doi.org/10.17652/rpot/2018.4.13727.

24. Gleriano JS, Fabro GCR, Tomaz WB, Forster AC, Chaves LDP. Family health team work management. Esc. Anna. Nery. 2021;25(1):e20200093. DOI: http://dx.doi.org/10.1590/2177-9465-EAN-2020-0093.

25. Lourenção LG. Qualidade de vida, engagement, ansiedade e depressão entre gestores de Unidades da Atenção Primária à Saúde. Rev. port. enferm. saúde mental. 2018;(20):58-64. DOI: http://dx.doi.org/10.19131/rpesm.0227.

26. Ferreira SRS, Périco LAD, Dias VRFG. The complexity of the work of nurses in Primary Health Care. Rev. Bras. Enferm. 2018;71(suppl 1):704-709. DOI: http://dx.doi.org/10.1590/0034-7167-2017-0471.

27. Kneodler TS, Paes GO, Porto FR, Nassar PRB, Oliveira AB. Nursing throughout war times: political propaganda and professional valorization (1942-1945). Rev. Bras. Enferm. 2017;70(2):407-414. DOI: http://dx.doi.org/10.1590/0034-7167-2016-0440.

28. Rodrigues ACA, Bastos AVB, Moscon DCB. Delimiting the concept of organizational commitment: empirical evidence of the overlap between the entrenchment and the continuance mindset. Organ. Soc. 2019;26(89):338-358. DOI: http://dx.doi.org/10.1590/1984-9260897.

29. Lourenção LG, Oliveira JF, Ximenes Neto FR, Cunha CLF, Valenzuela-Suazo SV, Borges MA, et al. Career commitment and career entrenchment among Primary Health Care workers. Rev Bras Enferm. 2022;75(1):e20210144. DOI: http://dx.doi.org/10.1590/0034-7167-2021-0144.

30. Costa IP, Moreira DA, Brito MJM. Meanings of work: articulation with mechanisms of risk and protection for resilience. Texto Contexto Enferm. 2020;29:e20190085. DOI: http://dx.doi.org/10.1590/1980-265x-tce-2019-0085. 